\title{
Challenges of Water Sensitive Cities in Mexico: The Case of the Metropolitan Area of Guadalajara
}

\author{
Jose Arturo Gleason ${ }^{1, *(D)}$ and Cesar Casiano Flores ${ }^{2,3}$ (D) \\ 1 Department of Techniques for Construction, University Centre for the Arts, Architecture and Design, \\ University of Guadalajara, 44250 Guadalajara, Mexico \\ 2 Public Governance Institute, Parkstraat 45-box 3609, KU Leuven, 3000 Leuven, Belgium; \\ cesar.casiano@kuleuven.be \\ 3 Insituto de Investigaciones en Medio Ambiente Xabier Gorostiaga S.J, Universidad Iberioamericana-Puebla, \\ 72820 San Andres Cholula, Mexico \\ * Correspondence: arturo.gleason@cuaad.udg.mx; Tel.: +52-3313-3117-12
}

Citation: Gleason, J.A.; Casiano Flores, C. Challenges of Water Sensitive Cities in Mexico: The Case of the Metropolitan Area of Guadalajara. Water 2021, 13, 601. https://doi.org/ 10.3390/w13050601

Academic Editor: Robert Sitzenfrei

Received: 2 February 2021

Accepted: 20 February 2021

Published: 25 February 2021

Publisher's Note: MDPI stays neutral with regard to jurisdictional claims in published maps and institutional affiliations.

Copyright: (c) 2021 by the authors. Licensee MDPI, Basel, Switzerland. This article is an open access article distributed under the terms and conditions of the Creative Commons Attribution (CC BY) license (https:// creativecommons.org/licenses/by/ $4.0 /)$.

\begin{abstract}
Mexico is currently facing important water management challenges. Cities in the country are facing water scarcity and at the same time they struggle with floods during the raining season. The water sensitive urban design (WSUD) approach has proved to be helpful around the world in tackling urban water challenges such as floods or water scarcity. The WSUD approach highlights the role of both the water cycle and the water utilities systems, when transitioning towards a water sensitive stage. Therefore, the objective of this research is to demonstrate the relevance for cities of a WSUD approach by analyzing the current situation of the water cycle and the water utility in the Metropolitan Area of Guadalajara (MAG). This research proposes a case study approach. Within our case of study, we focused on the water cycle and the water utilities system (Sistema Intermunicipal de los Servicios de Agua Potable y Alcantarillado (SIAPA)) and ask two questions: (1) What are the causes of water scarcity and flooding in the MAG? and (2) What are the proposals to solve these problems under a WSUD approach? By answering these questions, we identified that the water management in the MAG corresponds to a single purpose infrastructure. This type of water management is common in developing cities and does not contribute to solve the problems of water scarcity and floods. The water supply policy is based only on the construction of large dams disregarding the storage and use of rainwater, and reuse of greywater, and water-conservation devices. In order to transition towards a water sensitive stage, changes in the water policy need to take place and a WSUD approach that includes multi-purpose infrastructure, should be considered.
\end{abstract}

Keywords: water sensitive urban design; water sensitive city, water cycle; water utilities; water scarcity; flooding

\section{Introduction}

Currently, urban areas worldwide are facing numerous water scarcity challenges such as delivery of drinking water supply, wastewater production, and depleted aquifers [1], and at the same time water urban flood recurrences are increasing, due to factors such as climate change, population growth, changes in land use and aging or inadequate infrastructures [1]. The analysis of both scarcity and flood challenges in urban areas is important because while cities cover just $1 \%$ of the Earth's surface, they produce $80 \%$ of the GDP and host $54 \%$ of the population [2]. Cities are complex systems where various actors and processes interact through geographic, institutional and governance scales [3]. This complexity creates challenges when implementing strategies to solve water scarcity and flood challenges. Their solution and climate change adaptation require strategic investments to deliver sustainable solutions in the long-term [4]. The type of adaptation depends on the cultural, technological, economic, and governance contexts [5]. 
Understanding the challenges of the water sector and climate change, a framework for water adaptation issues at the city level was developed by the Cooperative Research Centre for Water Sensitive Cities in Australia (CRCWSC). They created the concept of "water sensitive cities" (WSC) with the idea that nowadays the largest part of the population lives in urban areas and it is necessary to transition to a sustainable water management in the city [4]. They propose a transition framework that allows benchmarking at the macro-scale by establishing a typology of six city stages. Figure 1 below shows the evolution process proposed by the Urban Water Management Transitions Framework (UWMTF) [4]. The final goal in this water transition framework is for a city to reach a WSC stage.

Cumulative Socio-Political Drivers

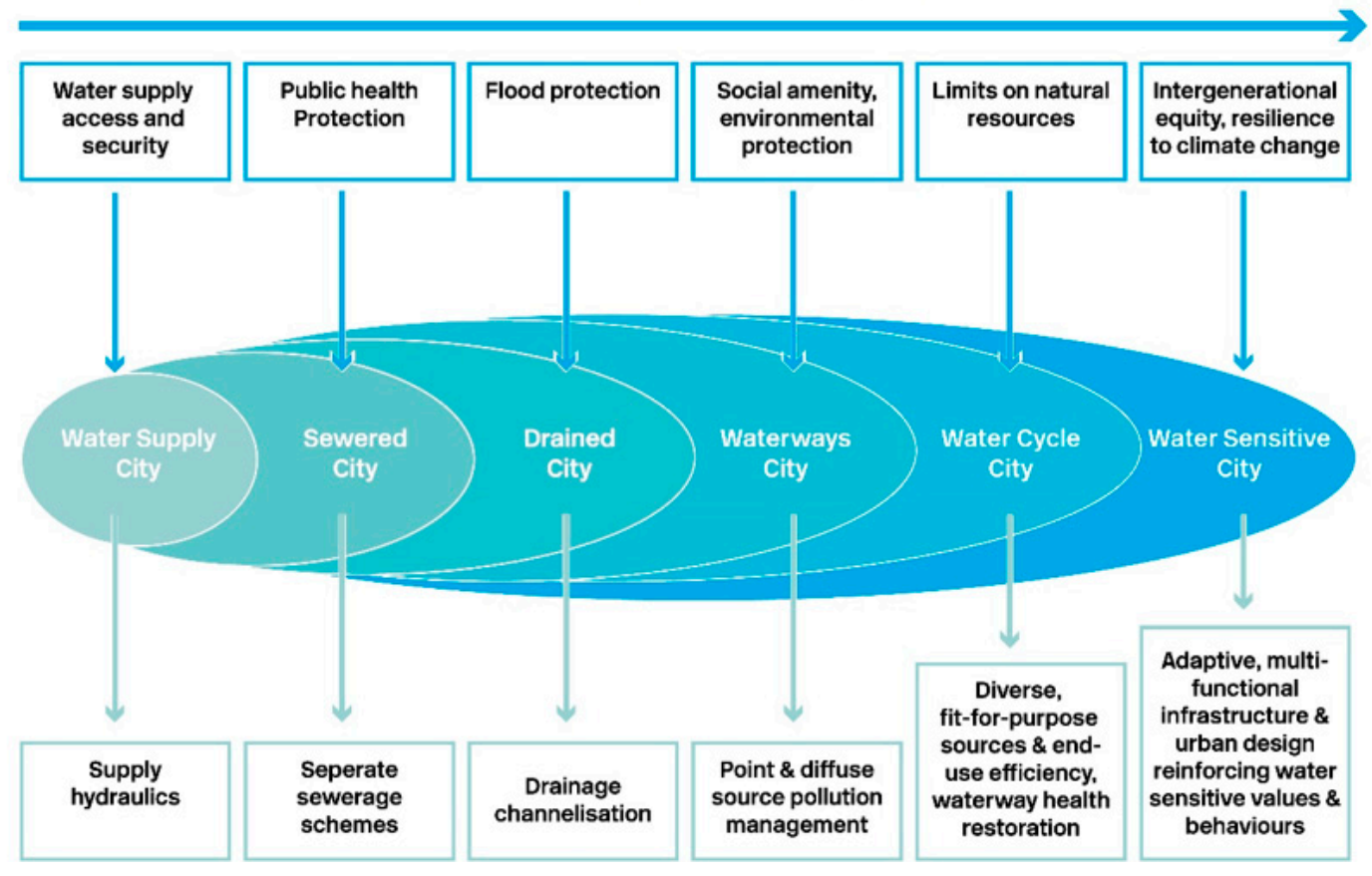

Figure 1. Urban Water Management Transitions Framework [4].

The first three stages describe the evolution of the water system to provide essential services: Access to potable water (Water Supply City), public health protection (Sewered City) and flood protection (Drained City). These three stages are followed by the Waterways City, Water Cycle City and ultimately a Water Sensitive City. The last three stages describe the evolution towards a higher order of services. These are: Social amenity and environmental protection, provide reliable water services under a constrained resources context, and ensure intergenerational equity and resilience to climate change [6]. In general, while the three first stages are critical for a city, the last three stages respond to broader needs of society since "people value ecological health, amenity, thermal comfort, beauty, and equity, characteristics that are influenced by water systems and considered to make a city livable" [7].

Developing cities tend to be located in the first three stages where cities have single purpose infrastructure. While developed cities tend to be located in the last three stages where there is multi-functional infrastructure and therefore a more advanced water management [8]. Multifunctional infrastructures are attractive for society and can combine urban ecology with safe and usable spaces [9]. Multifunctional infrastructure is also known as blue-green infrastructure (BGI) and it is a step forward from single purpose infrastructure. An example of single purpose infrastructure is grey infrastructure, which aims to remove the rainwater from the flooded area and to distribute it to the closest water body [10]. Although this grey infrastructure has proved to be effective in many cases, 
it also has negative aspects: (a) Changes the local hydrological cycle, (b) increases peak flows, (c) increases risks downstream, (d) changes groundwater and surface water levels, and (e) with the increase in extreme weather conditions, the capacity of the infrastructure is becoming inadequate [10]. Figure 2 below exemplifies the urban water management transition from a developing city to a developed city.

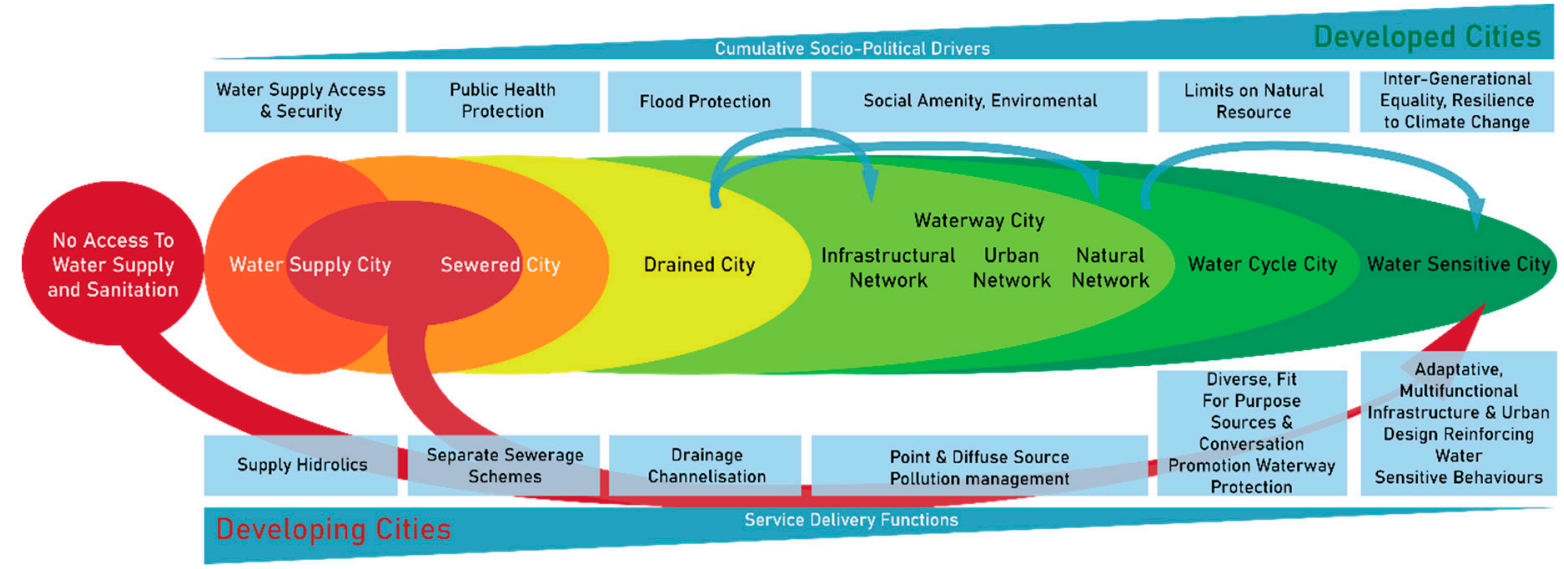

Figure 2. Adaptation of the UWMTF for leapfrogging of developing and developed cities [8].

BGI can be defined as a strategic and planned infrastructure network designed to deliver ecosystem services, to protect biodiversity and to provide multiple social services [10]. It can be classified in natural water features such as ponds, rivers, lakes, or wetlands or man-made features such as green buildings, streets or places [10]. A key aspect of BGI is its multi-functionality due to the interrelationship of the projects between the vegetation and the water cycle. In this sense, appropriate BGI is an urban park that absorbs runoff water excess and provides recreational opportunities [10]. It is under these circumstances that WSUD approach plays a relevant role. The WSUD addresses water quantity and quality issues in urban areas through integrated and natural solutions that include BGI when building infrastructure and landscapes in the cities [10].

The concept of WSC and WSUD have been accepted worldwide and related projects have been developed in Asia [11], Europe [12], and Latin America, including Mexico [13]. However, in the case of Mexico academic research considering a WSUD approach is still limited. Among the few studied cities are Mexico City [14-16], San Pedro Cholula [17], and Mineral de la Reforma [18]. Considering the embryonic state of this topic in Mexico and that $78 \%$ of the Mexican population lives in cities, this research aims to contribute to the WSC and WSUD literature, by focusing in the Metropolitan Area of Guadalajara (MAG).

The MAG is located in the western part of Mexico and its water management exemplifies the water challenges that most Mexican cities face. When looking at the water infrastructure in the MAG and its problems, there is a paradox since the city faces both problems water scarcity and floods [19]. On one hand more than $55 \%$ of rainwater is drained into the sewage system, and on the other hand, the aquifers are drying due to their overexploitation [20]. Faced with this situation, the local government has proposed the construction of large dams where small communities are located and they will be flooded to create El Zapotillo Dam [21]. This policy is not considering reverting the damage to the water cycle caused by disorderly urbanization sprawl, and the poor services provided by the water utility in the MAG. The water management approach in Guadalajara in the last 40 years, has been focused on overexploiting the water sources and draining the rainwater.

Against this background, this exploratory research analyses the water problems of scarcity and floods in the MAG by focusing on the water cycle and the services provided by the water utility named Sistema Intermunicipal de los Servicios de Agua Potable y Alcantarillado (SIAPA). The first includes catching the rainwater from rooftops; infiltration 
of water into the ground using trenches, wells, swales or impermeable concrete to increase evapotranspiration via trees and green areas. The second focuses on the implementation of monitoring systems in the different water utility systems, this includes water distribution infrastructure; wastewater treatment systems and campaigns to favor the sustainable use of water at the household level. By analyzing on the water cycle and the water utility, this article also demonstrates the importance of a WSUD [22]. The relevance of the study relies on the fact that water scarcity and floods are becoming more common in Mexico and these challenges are present in the most important Mexican cities [19]. Due to its geographical position Mexico is subject to extreme weather phenomena every year [1]. Additionally, if the current situation continues, it will be complicated to reach the Sustainable Development Goals (SDGs) in 2030 [23].

\section{Materials and Methods}

This study includes both positivist and interpretivist approaches [24]. The positivist approach consists in contrasting existing hypothesis to test an existing theory, using the deductive method. Meanwhile, the interpretivist approach consists in the construction or generation of one theory from the series of propositions drawn from a theoretical perspective that works as a starting point for the researcher, using the inductive method [25].

From the interpretivist approach and inductive method, emerges the Case Study method. Case Study is a research design that traditionally involves in-depth study using a range of techniques over a lengthy time period to produce detail information [26]. Case studies are analysis of persons, groups, events, decisions, periods, policies, institutions or other systems that are studied holistically by one or more methods [27] and can contribute to the cumulative development of knowledge [28]. Yin [29] considers that the Case Study method is appropriate to investigate new cases and it has the following features:

- Examines or inquires over contemporary phenomenon in its real context;

- The borders between the phenomenon and its context, are no evident clearly;

- Various sources of information are utilized; and

- It can include one or more cases.

Yin proposes a way of thinking of design of the research including five important components:

- Research questions;

- Theoretical propositions;

- Unit or units of analysis;

- Logic relationship from data to the propositions; and

- Criteria for interpretation of data.

Considering the case study features aforementioned, this exploratory research uses a qualitative or interpretivist approach. The focus of this study relies on the analysis of the water management challenges in the MAG. The challenges of the MAG are not unique, on the contrary, they are similar to those that can be found in other metropolitan areas in Mexico such as Puebla, Monterrey, or Mexico City $[17,19,30]$. Our study can help to set the main causes of the problematic and define the solutions based on WSUD approach and Water Sensitive City theory [30]. The analysis for this research is outlined in Figure 3.

In this exploratory research, we have focused on the water cycle and the water utility operation due to their strong relation and because the integration of the water cycle in the urban infrastructure is key for the WSUD approach. The WSUD approach includes improving functional water infrastructure and a comprehensive water cycle management [31]. 


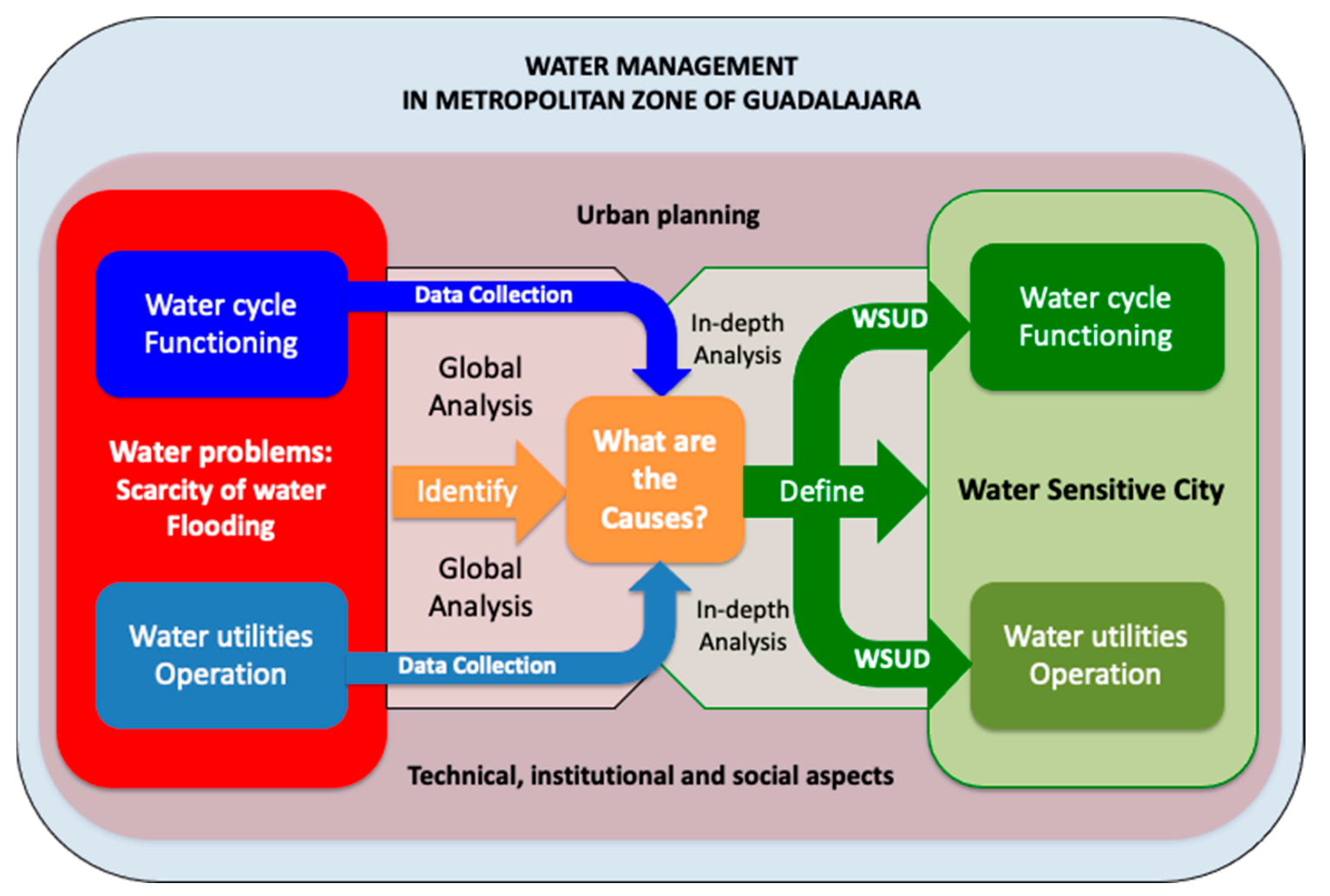

Figure 3. Analysis of the case study.

\subsection{Case of Study}

The MAG is the second largest urban area in Mexico and it is located in the western part of the country. Figure 4 shows the three watersheds that are included in the MAG: Río Blanco river, Atemajac Valley and El Ahogado. Guadalajara, the largest city in the metropolitan area, was founded in 1542 near the River San Juan Dios located in Atemajac Valley watershed. Guadalajara is the capital of Jalisco and together with the municipalities of Zapopan, San Pedro Tlaquepaque, Tonalá, Tlajomulco de Zúniga, El Salto, Ixtlahuacán de los Membrillos, and Juanacatlán create the MAG. The MAG has a population of approximately 5 million inhabitants, an annual population growth of 1.7\% [32] and occupies a surface of $2734 \mathrm{~km}^{2}$ [33].

According to SIAPA the water supply per capita is 205 liters per inhabitant in the MAG [33]. Yet, water scarcity is a serious problem. There is a groundwater deficit of $-11.091327 \mathrm{Mm}^{3}$ per year [34] and wastewater treatment is estimated around $1.9 \%$ [34] affecting the reuse of water. At the same time more than 300 flood risk areas have been identified in MAG [35] and the estimated economic losses are 50 million US dollars yearly [36]. Urban growth has covered almost $70 \%$ of the surface through the construction of houses, streets and roads, impacting the natural water cycle. Besides, urban sprawl and change in the land use [37]; population growth, poor water management, and lack of urban planning have been identified as key contributors to water problems in the MAG [35]. Being two of the most important problems floods and water scarcity [19]. Furthermore, it is expected that these challenges increase due to the effects of climate change in the region $[19,38]$. 


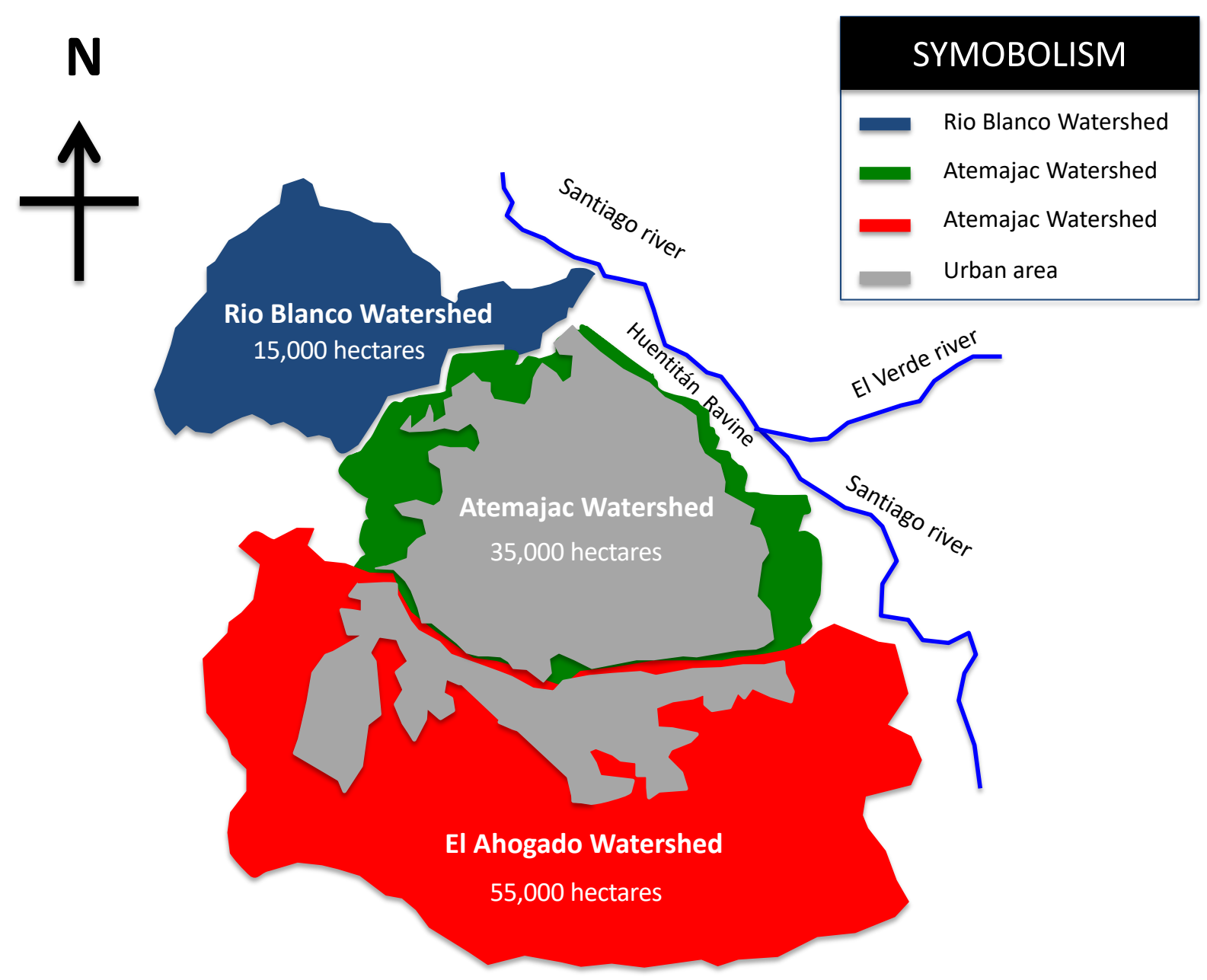

Figure 4. Metropolitan Zone of Guadalajara and its watersheds.

The SIAPA is in charge of the water policy and its management in the MAG. It is a governmental and intermunicipal body that was created in 2013. It provides the services of drinking water, sewage infrastructure, and wastewater treatment. It can coordinate actions with the state and federal governmental levels, and it is in charge of the strategies for water conservation and use [39]. Usually in the Mexican water governance system, the water utility or the local government proposes the different infrastructure projects based on the National Development Plan and the federal government programs' guidelines, called Rules of Operation. These Rules of Operation include the different conditions to finance the water related projects [40]. The federal program that supports the creation of rainwater infrastructures for drinking water, sewage, rainwater collectors or infiltration wells is called PROAGUA (Program for drinking water, drainage and wastewater treatment) [17]. A current example of one of the most important infrastructure projects for water supply in the MAG and cities in other state, is the construction of the Zapotillo Dam, the sources of investment are the federal government $57 \%$, State government $3 \%$, private companies $23 \%$, and trusts $17 \%$ [37].

Following the Case Study methodology and focused on the water cycle and the water utility infrastructure, the WSUD approach provides the perspective of analysis and defines the proposals [22] of this research. The research questions for this case study are: (1) What are the causes of water scarcity and flooding in the MAG? (2) What are the proposals to solve these problems under a WSUD approach? These questions have the purpose of obtaining the necessary evidence to demonstrate the relevance for cities of a WSUD approach. 


\subsection{Procedures}

The key information obtained for this research was collected data by the first author. He has conducted water research in the MAG since the year 2000. This includes government information, several field visits to both the watershed regions and the water utility infrastructure, analysis of academic studies, interviews with water public servants, and debates with political actors. The methodological procedure of this research is shown in Figure 5.

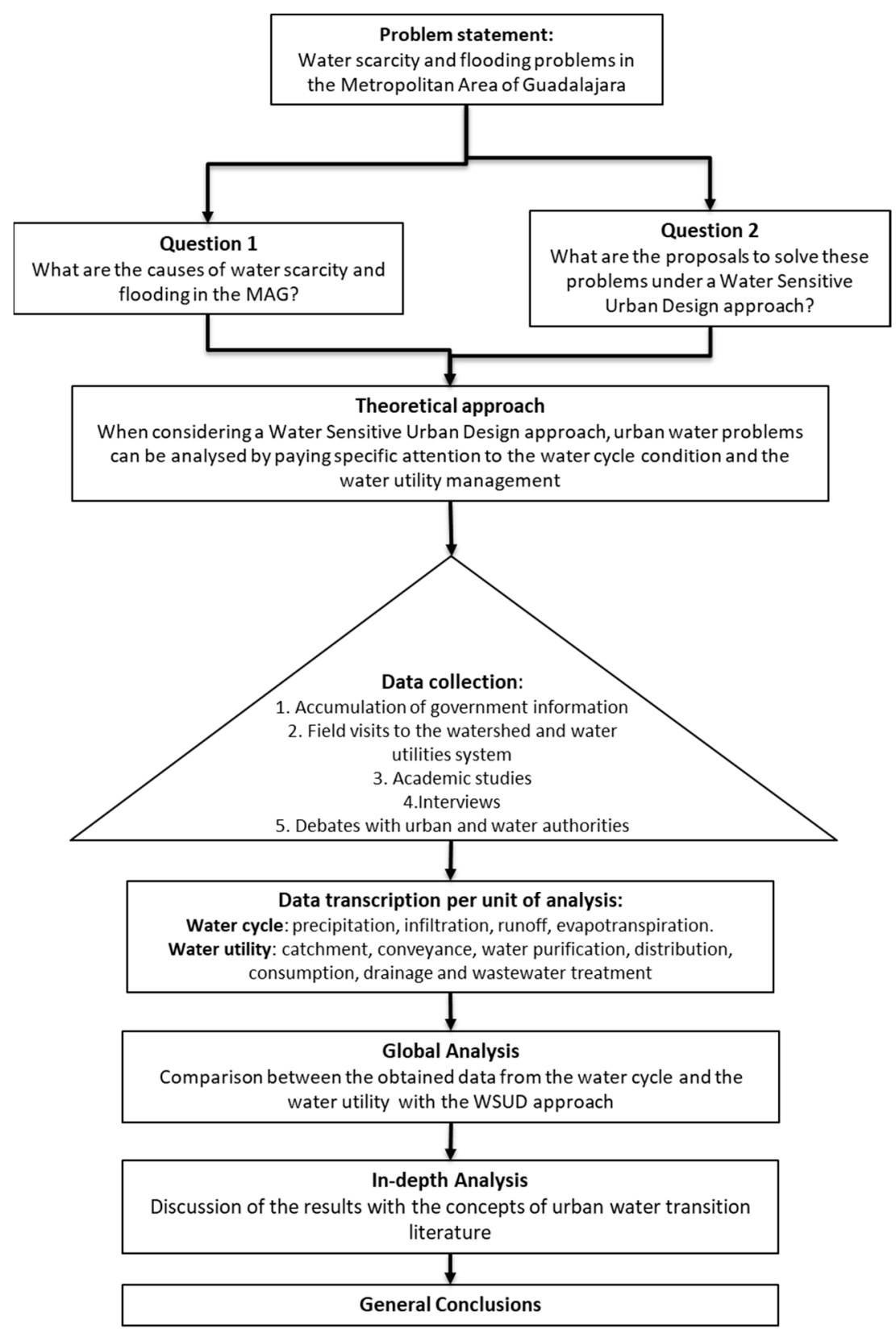

Figure 5. Methodological procedure of the study.

\subsection{Data Collection}

The data was collected from the water cycle monitoring system. To do so, we revised the available information for the national and local weather systems. This included rainfall magnitude and intensity, evaporation and evapotranspiration. The revision for surface monitoring and groundwater flows were also reviewed. The data collection included visits 
to understand the conditions of the water cycle in urbanized areas and to verify if there was a water cycle monitoring system.

Secondly, the government data bases of the water utility system were revised to know the conditions under which is functioning. The revision also helped to obtain data such as supply and drainage flow, the capacities of the wastewater treatment plants, water distribution and drainage system network conditions, waterflow meter devices capacities, and the organizational structure of the water utility.

Thirdly, local and regional academic literature about the water problematic was reviewed. Surveys carried out by local universities, shows the hard work that academics have done during the last 20 years [41-43]. The literature of WSUD and WSC has been analyzed by the authors to provide a theoretical body for this study [22,44-46]. Also, as part of academic work, the first author has participated in debates with water local authorities. The debates have helped to know better the point of view and the reasoning of the water authorities [47].

\subsection{Data Transcription}

The data was organized in two categories: The parameters of the water cycle and the water utility. In the case of the water cycle the data parameters in the MAG are very limited [48]. The only known is rainfall which is estimated at $897 \mathrm{~mm}$ per year [34]; surface runoff, ground water flow and evapotranspiration are unknown.

In the case of the water utility, its system has seven phases: Water supply sources, conveyance system, purification, water distribution, consumption, and drainage and waste treatment system. The data from the water utility was organized considering each phase of the system. The main data is shown in the Table 1 [49].

Table 1. Data of each phase of water utilities system.

\begin{tabular}{ll}
\hline \multicolumn{1}{c}{ Parameter } & \multicolumn{1}{c}{ Data } \\
\hline & 1.1 Chapala $58 \%,\left(5.889 \mathrm{~m}^{3} / \mathrm{seg}\right)$ \\
1. Water supply sources & 1.2 Groundwater $28 \%\left(2.796 \mathrm{~m}^{3} / \mathrm{seg}\right)$ \\
& 1.3 Calderon $13 \%\left(1.287 \mathrm{~m}^{3} / \mathrm{seg}\right)$ \\
2. Conveyance system & 1.4 Springs $1 \%\left(0.120 \mathrm{~m}^{3} / \mathrm{seg}\right.$ \\
3. Purification & $50 \mathrm{~km}$ of length of tubes. \\
4. Water distribution system & Miravalle Plant $\left(6 \mathrm{~m}^{3} / \mathrm{seg}\right)$ \\
5. Consumption Household level & San Gaspar Plant $\left(1 \mathrm{~m}^{3} / \mathrm{seg}\right)$ \\
6. Drainage System & $8500 \mathrm{~km}$ of tubes \\
& 850,000 connections to houses \\
& $500 \mathrm{~km}$ of water collectors \\
7. Wastewater treatment capacity & 7.1 El Ahogado Plant $\left(1.45 \mathrm{~m}^{3} / \mathrm{seg}\right)$ \\
& 7.2 Agua Prieta Plant $\left(3.92 \mathrm{~m}^{3} / \mathrm{seg}\right)$ \\
& 7.3 Rio Blanco $\left(0.122 \mathrm{~m}^{3} / \mathrm{seg}\right)$ \\
& 7.4 Virreyes Plant $\left(0.023 \mathrm{~m}^{3} / \mathrm{seg}\right)$ \\
& 7.5 North Tonalá Plant $(0.011 \mathrm{~m} / \mathrm{seg})$ \\
& 7.6 El Vado Sur Plan $\left(0.058 \mathrm{~m}^{3} / \mathrm{seg}\right)$ \\
\hline
\end{tabular}

\subsection{Global Analysis}

Based on our qualitative research approach, we proceeded to an inductive analysis, guided by the WSUD framework. The intergovernmental agreement on a National Water Initiative defines WSUD as "the integration of urban planning with the management, protection and conservation of the urban water cycle, that ensures that urban water management is sensitive to natural hydrological and ecological processes" [22]. The term WSUD compromises two parts "Water Sensitive" and "Urban Design". Urban Design is a well-stablished field associated with the planning and architectural design of urban environments, covering issues that have traditionally appeared outside of the water topic, but which actually have environmental effects on land and water. WSUD brings 'sensitivity to water' into urban design, i.e., it aims to ensure that water is given priority within 
the urban design processes. The words "Water Sensitive" define a new paradigm of an integrated urban water cycle management that includes various disciplines of engineering and environmental sciences associated with the provision of water services, including the protection of aquatic environments in urban areas. Community values and aspirations of urban places necessarily govern urban design decisions and therefore water management practices. Collectively WSUD integrates the social and physical sciences" [50]. WSUD is centered on integration at a number of levels:

- The integrated management of the three urban water streams of potable water, wastewater and stormwater.

- The integration of the scale of urban water management from individual allotments and buildings, to precincts and regions.

- The integration of sustainable urban water management into the built form, incorporating building architecture, landscape architecture and public art.

- The integration of structural and non-structural sustainable urban water management initiatives.

Once the government documents were analyzed, some visits to watershed and water utilities took place in order to obtain the data of the water cycle and the water utilities systems. Based on this information a comparison was made between the obtained data and the WSUD framework. Table 2 shows the differences between elements of conventional and sensitive water management in the MAG and based on Newman proposal [51].

Table 2. Differences between elements of conventional and sustainable water management.

\begin{tabular}{|c|c|c|}
\hline Category & Conventional & Sensitive \\
\hline Water Supply & $\begin{array}{c}\text { Large Dams } \\
\text { Large Pumps and long Conveyance } \\
\text { Groundwater bores }\end{array}$ & $\begin{array}{c}\text { Supplemented by community groundwater } \\
\text { schemes as a secondary supply for all outdoor use } \\
\text { in households and for POS }\end{array}$ \\
\hline Water Conservation & $\begin{array}{c}\text { Neither interior nor exterior water } \\
\text { conservation devices }\end{array}$ & $\begin{array}{c}\text { Application of low water use applications } \\
\text { and technologies }\end{array}$ \\
\hline Public Open Spaces (POS) & $\begin{array}{l}\text { Design dominated by high water use plants } \\
\text { and they are polluted }\end{array}$ & $\begin{array}{l}\text { Design based on water sensitive urban design } \\
\text { (WSUD) techniques }\end{array}$ \\
\hline Sewerage & $\begin{array}{c}\text { Standard reticulation systems } \\
\text { without planning }\end{array}$ & $\begin{array}{l}\text { Full recovery of water used in POS rather than } \\
\text { direct linkage to main }\end{array}$ \\
\hline Stormwater & $\begin{array}{l}\text { Large sums and piped systems only to drain } \\
\text { the rainwater without treatment }\end{array}$ & $\begin{array}{c}\text { Application of WSUD and Best Management } \\
\text { Projects concepts }\end{array}$ \\
\hline
\end{tabular}

\section{Results}

When looking at Table 2 above, we can see that the current water management is still within the first stages of the UWMTF and it is very different from the WSC approach. Therefore, we can deduce that the type of water management in the MAG corresponds to a single purpose infrastructure and contributes to the problems of water scarcity and floods. Changes are required in order to guarantee the water availability for present and future generations. The sub-sections below will present the results obtained from the in-depth analysis, obtained through the comparison of the results with the WSUD concepts.

\subsection{Findings about the Water Cycle Functioning}

The lack of a planned urbanization has deteriorated the water cycle. The consequences can be observed in the floods and depletion of the aquifers. The economic losses are in order of the 50 million US dollars because of floods in the MAG yearly [36]. The availability of groundwater is descending critically, the authority stated there is a deficit in both aquifers (Atemajac and Toluquilla) in the MAG. Table 3 shows the deficits from both aquifers, Atemajac [52] and Toluquilla [53]. 
Table 3. Situation of Aquifers in the MAG.

\begin{tabular}{cccc}
\hline Aquifer & Recharge $\mathbf{M m}^{\mathbf{3}}$ /year & Extraction $\mathbf{M m}^{\mathbf{3}}$ /year & Deficit $\mathbf{M m}^{\mathbf{3}} /$ year \\
\hline Atemajac & 147.3 & 158.39 & -11.09 \\
Toluquilla & 49.1 & 121.41 & -72.31 \\
\hline
\end{tabular}

$\mathrm{Mm}^{3}$ : Millions of Cubic Meter.

The analysis of the urban planning documents, helped to identify that the water cycle does not have prominence in urban planning as the WSUD states [54]. Thus, a protection strategy for the water cycle is absent. The urbanization of recharge zones are proof of this absence of protection [55]. The policy is oriented only to meet the water demand and mitigate the floods using single purpose infrastructure, disregarding the construction of multi-functional infrastructure or the restoration of water cycle through BGI. These characteristics place the policy in the MAG within the first three stages of the UWMTF. Additionally, under these circumstances, it seems the policy will not change, and the water problems will continue increasing in the MAG.

The current condition of the water cycle is not taken into account in the urban planning and the provision of water services together with the constant flooding are proof of this [56]. There is no sensitivity to water urban design, the deterioration of the watershed shows that the urban area has covered a large area of MAG surface. This can be observed in the absence of green areas. Currently, the MAG is mostly covered by grey surfaces as it is estimated that the surface of green areas per inhabitants is $1.4 \mathrm{~m}^{2}$ while the recommendation is $9 \mathrm{~m}^{2}$ [57]. The disciplines of engineering and environmental sciences are not associated with the provision of water services. These types of challenges have been identified in other Mexican cities such as San Pedro Cholula [17]. The general approach only relies on the satisfaction of water demand. The construction of the Zapotillo Dam is the principal planned project to meet the scarcity of water in the MAG. The budget of this project does not include any integration and protection to the water cycle [58].

\subsection{Findings about the Water Utilities System, SIAPA}

The intensive and accelerated housing building has been one of the main drivers of urban development. The construction of urban developments has affected the hydrology configuration of the territory, such as the construction of housing in the riverbed, which has caused floods in the last two years [59]. Another example is observed when high tower buildings are constructed, and their foundations hinder the groundwater flows; this provokes floods in their basements. Then, the water has to be pumped to the municipal drainage system [60].

The SIAPA and local authorities have simply ignored the inventory of the water supply and sewerage infrastructure. Thus, the new urban developments do not offer good water services for water supply and sewerage [61]. The implementation of water conservation systems in the planning of the SIAPA is not included. A water supply policy based only on the construction of large dams prevails disregarding the storage and use of rainwater, the reuse of greywater, or the implementation of water-conservation devices. This is observed in the definition of public policies and budgets. The budget is focused on the planning of a large dam and deep drainages, not in protection of aquatic environments [62]. The water cycle and the water utility are not integrated into a comprehensive system, each one is functioning separately. A disconnection of the three-urban water streams, drinking water, wastewater and stormwater is present in the current water management. A linear system and a single purpose infrastructure policy prevail in the functioning of different services provided by the SIAPA, which is disconnected to the water cycle and urban planning. The reduction of demand of water is not encouraged neither; the approach is to increase the water supply.

In general, the infrastructure developed by the SIAPA has lacked a proper planning. Today, it is impeded to cover the total domestic water demand, there is insufficient stormwater drainage and wastewater treatment infrastructure. The consequences of these 
deficiencies are among the reasons for increasing water scarcity in the city, the constant floods during the rainy season, and the persistent contamination of water bodies, especially in the Santiago River [63].

\subsection{Findings about the Current Water Management of the MAG}

One outstanding finding is the lack of a robust monitoring system for the water cycle. The precipitation information is incomplete, not all the weather stations work correctly, so the meteorological systems are weak. Hence, they do not provide accurate real-time and historical information. During the field visits it was not possible to identify aquifers' monitoring systems that could show the quantity and quality of underground water, the locations of underground water flows or piezometric level. A National Water Information system was founded but its data is incomplete as shown in the website of the National Water System [64].

The same situation was identified with surface water, there is no monitoring system that can measure in real-time the quantities of surface flow and the location of waterways [65]. There is no data regarding extractions from current sources in terms of quality and quantity. Neither about the rate of water losses in the water distribution system because of leakage. The percentage of acceptable losses by international standards is $10 \%$ minimum of the total of the water distributed [66]. The measurement of household consumption is unknown; the inhabitants of the MAG rarely pay their real consumption. The current water management is carried out with absence of basic technical information that can support the planning and the construction of new alternatives.

The lack of an integral water management is demonstrated in the pollution levels of the Santiago river, which is considered the most polluted water body in Mexico [67]. In the urban planning, the water is just considered another element among other environmental issues [68]. This contradicts the WSUD approach that establishes that water management should bring "sensitivity to water" into urban design. In other words, the water does not have prominence within the urban design processes. This absence of prominence can be observed in the document of Metropolitan Land-Use Management of the MAG (POTMET, abbreviations in Spanish) published by the Metropolitan Planning Institute (IMEPLAN, abbreviations in Spanish) [54]. A focus in water supply and drainage prevails throughout the document.

The Figure 6 below, shows the state of the water cycle and hydro-sanitary system. Both systems (natural and artificial) are related strongly by problems that affect each other. The water cycle has problems that should be addressed, and the hydro-sanitary system needs rehabilitation. These systems have to be integrated for getting a WSC through a WSUD approach.

The first step to the integration of natural and artificial system is shown in Figure 7. The water cycle is restored through interventions in the watershed, that include recharging the aquifers and rescuing polluted rivers. The artificial system can be rehabilitated through the repair of leaks in water supply network, the separation of the drainage, implementation of rainwater harvesting systems and both the creation and operation of wastewater treatment plants. The restoration and rehabilitation could be possible by considering a WSUD approach. 


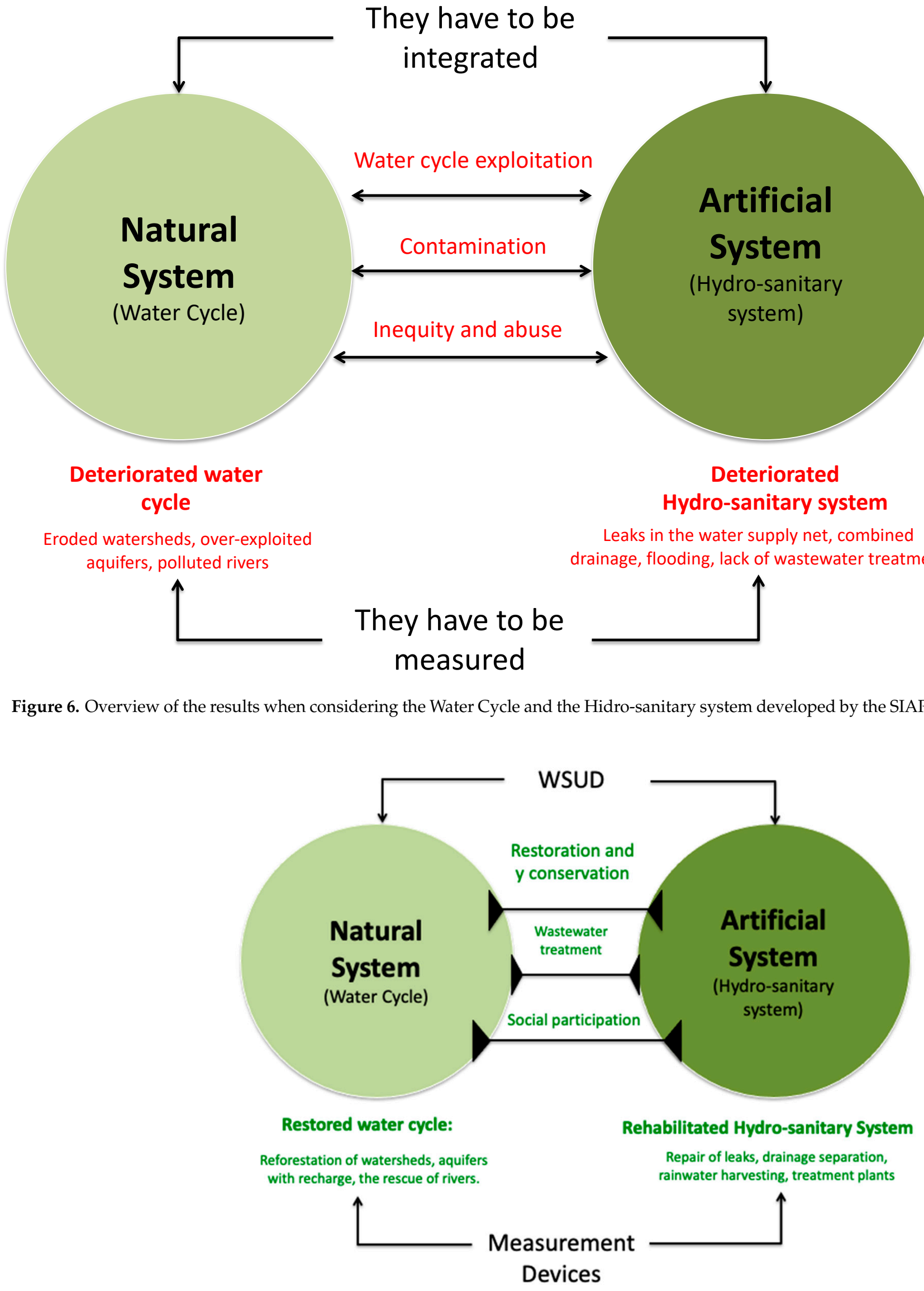

Figure 7. Integration of natural and artificial system. 


\section{Discussion}

The strong relationship between the water cycle and the water utility has been reported in this article. While this study has presented an analysis of the current situation of the water cycle and the SIAPA, it is necessary to study further the relationship between the water cycle and the water utility system, considering the sustainable view that WSUD provides.

The deterioration of the water cycle is an issue ignored in the water public agenda. The deterioration is growing and there is no governmental action to change this situation. If the water cycle continues being ignored in urban planning, how can be assured the availability of water in the short and the long-term? How the water resources will be planned if their quantity and quality are unknown? How the water will be distributed in an appropriate and efficient manner? It is even surprising that the budgets are formulated without water balance information.

Due to the absence of considering the water cycle in urban planning, most of the urban developments are authorized without knowing the water availability that can guarantee the water supply for the present and future inhabitants of the MAG. The lack of this information fosters the urban disorder that affects the water bodies in terms of quantity and quality. Some urban developments are built on recharging aquifer zones where the leakages of wastewater infiltrate into the aquifer. Most of the consumers do not receive constant water supply services, nor an efficient sewage water collection, and there is not a wastewater treatment. Also, hydrology as well as hydrogeology behaviors are ignored, the floods cause enormous human and economic losses as it has been seen in the case of urban development around the river [59]. The lack of technical information limits a design of water policies sensitives to the water cycle. The lack of technical information prevails in the water utility systems and increases the water problems. The number of extractions from current water sources is unknown, and it prevents an appropriate distribution among the consumers. Some of the inhabitants receive too much water and others too little or even nothing. Even when the water utility makes some calculations, the data is inaccurate.

The knowledge regarding the quality of drinking water in real-time is one of the most important challenges. Today, the population needs to buy bottled water for drinking, because they do not trust the water that SIAPA supplies. There is no digital system that informs the quality of water in the distribution system to assure the water supply for the inhabitants. As the time goes and the water sources are contaminated, the risk of diseases is growing.

Another issue is the lack of accurate information on the water losses in the distribution system. In this respect, there are some official assumptions, but SIAPA does not have precise information. The government assumes $40 \%$ of losses throughout the 8500 kilometers of the water network. The annual cost of water production is about \$15 million USD, but then $40 \%$ of this money is lost.

The domestic use of water is not measured, so the payment is not based on the consumption. The water utility does not have an efficient payment system, which makes difficult the collection of the money to finance its tasks. In addition, local authorities do not encourage the consumers to implement water conservation devices, which together with the lack of measurements provokes a high level of water consumption. Instead of reducing the water demand, the policy is driven to increase the water supply.

Regarding the drainage system, it is a sensitive issue related with the health and security of the population. As it has been presented, the frequent flooding demonstrates the incapacity of the sewage system to conduct the water in an appropriate manner. During floods, the sewage water enters into the houses affecting the health of the inhabitants and destroying their belongings. The local government has conducted different actions but they have not solved the problems. They have been designed without taking into consideration technical information such as rainfall intensity, runoffs, and infiltration rates. The poorly designed infrastructure complicates the creation of appropriate solutions. This situation gets more complicated when the limits for sustainable use are not monitored so the risk 
is high, and an overuse is present at any time. Actually, the drainage system needs a deep rehabilitation.

One of the most important challenges is the insufficient wastewater treatment. Despite the creation of wastewater treatment plants, there is still a deficit of treatment. This is a common situation in Mexico [69,70]. The local government has proposed the construction of more plants, but the number of discharges are ignored in spite of the existence of monitoring systems. It has been observed that there is strong bias towards the construction of large treatment plants but the number and location of the discharges to water bodies is ignored. Lack of monitoring of the quantity and quality of wastewater flows make difficult to define the type of treatment. The wastewater treatment in general, is insufficient and inefficient [70]. Actually, when looking at wastewater treatment from a circular economy perspective important challenges still need to be overcome. Some of the reasons are the top-down water policy implementation perspective, the low availability of resources, the prioritization of short-term results together with the lack of enforcement of the "polluter pays" principle and the current linear model of water systems [71].

The results of this research show that the SIAPA needs to implement changes in the operation of its systems if they want the city to transition towards a more sensitive stage. The WSUD approach offers a wide range of techniques to accomplish it. Through the implementation of WSUD techniques the water cycle could be restored, and the water utilities system could be rehabilitated. These techniques can help to restore the functioning of the water cycle by the implementation of rainwater catchment systems because they may help to save water and reduce the floods. Currently important projects are starting to take place in this direction [72]. If the rainwater is storage in the buildings or houses, the water can be used for domestic consumption reducing the water demand [43]. This rainwater also can be infiltrated to recharge aquifers. This allows reducing the extractions from current water sources. Raingardens can help to retain and infiltrate rainwater reducing the runoffs as well as the swales and trenches [10]. These techniques reduce the inlets of runoff into the current drainage so it can work more efficiently.

Another technique considered by the WSUD is BGI projects. Yet, the implementation of this infrastructure is challenging since it requires the involvement of other governmental actors such as the Urban Development and the Environmental Secretaries at the three governmental levels. When considering the hierarchical and top down water governance system in Mexico, the development of such infrastructure faces important governance challenges [17]. Green infrastructure, for example, can help to restore the water cycle and to reduce urban heat and increase thermal comfort in the cities. When cities and towns are constructed, hard impervious surfaces and buildings replace vegetation and soil. This leads to the development of unique urban climates that are typically hotter than natural landscapes. Higher urban temperatures are caused by many factors including reduced shading, abundance of materials that absorb heat, reduced evapotranspiration and waste heat from infrastructure and vehicles. Research shows that vegetation, especially trees, can effectively mitigate urban heat [73]. All of these alternatives can support the restoration of the water cycle and the rehabilitation of the water utility infrastructure. The sponge city is an example of the implementation of WSUD approach [74].

Finally, the results show that the main approach of water management is focused on the construction of large works-dams and collectors-and the increasing of water supply. However, both the water cycle restoration and water utility infrastructure condition are ignored. The main focus of water management lies in resolving the consequences instead of addressing the causes. To favor an urban water management transition, it is necessary to stop the deterioration of the water cycle and start actions of restoration. It is also required to improve the operation of the water utility to guarantee better services for the inhabitants of the MAG. Increasing the capacity of dams and large deep drainage are solutions that strength a water management that belongs to the first three stages of the UWMTF, a common characteristic of developing cities, as shown in Figure 2. 


\section{Conclusions}

The results of this study indicate the relevance of taking into account in urban planning both the water cycle and the water utility due to their key role in the city urban system and because they are strongly related. Therefore, we propose a restoration of the water cycle considering WSUD strategies. This restoration can start with the implementation by the SIAPA, of an automatic monitoring water cycle system with the purpose to measure the water inlets (rainfall) and outlets (evaporation, evapotranspiration, runoff, and infiltration rate) to calculate a more accurate water balance. In this way, this information can help to propose a water balance strategy considering the water cycle. Accurate information about the conditions of the water cycle can help to plan water usage more efficiently. If the quantity and quality of water are known, the water availability and its distribution can be done in a more effective way. If the runoffs are measured, the design of collectors can be more precise. Nowadays the design is based on the application of empirical formulas that are useful but ignore the reality. This is one of the reasons why the rainwater collectors lack the capacity to deal with the rainwater runoffs appropriately. Accurate information can help to create strategies for urban growth, assuring the sufficient water supply and efficient drainage in the short and long term.

Some example of this could be the Automatic Hydrologic Information System of the Ebro river basin situated in Spain [75] or the USGS National Water Information System located in USA [76]. Such type of systems should be included as part of the urban planning tools. The appropriate implementation of WSUD techniques requires information regarding evaporation and evapotranspiration rates or infiltration capacity. For example, by knowing the infiltration rate, the design of a raingarden can be more efficient. Another action is the implementation of BGI projects. BGI supports better adaptation of cities to the climate change effects [10]. However, this adaptation means a shift from traditional infrastructure and single purpose infrastructure to a multifunctional infrastructure, which require the involvement of different governmental actors [17]. Some of the potential techniques are: The green roofs, rainwater harvesting, swales, rainwater gardens, infiltration trenches, multi-functional parks $[10,77]$, or green infrastructure itself.

The SIAPA should consider in its public budget the implementation of automatic monitoring systems for the water cycle in order to know the quantity and quality for making rationale distribution for usages. This can contribute to guarantee the water availability for the next years. The water utility systems also need to be monitored. The lack of knowledge regarding its current operation prevents to improve it. The monitoring system for the water utility systems should be included as part of the water management policy. If there was an Automatic Hydro-Sanitary Information System, the construction of hydraulic works could be more precise, and they could really help to improve the water supply and drainage problems. If the water utility had information about the conditions of the network, they could also detect the leakages and repair them. If the domestic consumption is monitored in real-time, the charges of the service could be fair and more efficient. If the behavior of the drainage system was monitored, the explosive limits could also be understood in order to avoid any possible accident.

Finally, if the wastewater discharges were monitored, the control of them could help to decrease the pollution of water bodies. All these actions should be reflected in the public budget that can support the implementation of a digitization system to measure all the parts of the system. This type can provide technical information to reach an urban planning sensitive to water.

Hence, we propose that the WSUD approach should be considered to be implemented in the MAG. A WSUD public policy could support a transition towards a WSC stage. The restoration of the water cycle could be possible through WSUD techniques. The University of Guadalajara have made some pilot projects such as rainwater catchment systems, stormwater models, educational water programs; but it is necessary to implement more pilot projects in order to strengthen this innovative approach [77]. The literature on urban water transition has emphasized the important role that pilot projects have $[17,78]$. It is also 
necessary the rehabilitation of the water utility systems, starting with the implementation of monitoring systems. Through these actions the transition towards a WSC stage can be supported. This requires that the water cycle be included in the urban planning; otherwise, problems might be likely to increase. The deterioration can be reduced if the restoration of the water cycle and rehabilitation of water utilities are accomplished.

The current water management is still in the early stages of the UWMTF, focused on a single purpose infrastructure, typical of a developing city. Since there are still issues regarding wastewater treatment and there is no flood control, it seems that the MAG mainly belongs to the Sewered city stage. This management at this stage does not guarantee the water availability to present and future generations, nor solve the flood problems. The model of water management needs to transition towards a sustainable water management, which can be reflected in multi-purpose or BGI projects. This transition is urgent to be implemented in the MAG to ensure water sustainability and to accomplish the SDGs. Finally, this study is an effort to contribute to the development of the WSC concept in the Mexican context and to contribute literature on transition of cities towards a WSC stage. This study can be replicated in other large metropolitan areas in Mexico, such as Monterrey, Puebla or Mexico City. Yet, this study still faces important limitations. Being the most important the lack of relevant or accurate data regarding the water cycle and the water utility services. Therefore, while this article contributes to point out this problem, further studies to address these issues should be conducted. Also, while this article has focused on technical aspects of the water utility and the water cycle, there are still important gaps in the literature, for example the potential of urban vegetation and greenery to reduce this risk. Also, further research regarding BGI implementation should be conducted not only to support climate resilience but also to contribute to a healthy and attractive city environment. Finally, we encourage other researchers to focuses on the institutional and governance challenges that the implementation of this multi-functional, BGI or green infrastructure can face in the Mexican context.

Author Contributions: Conceptualization, J.A.G.; methodology, J.A.G. and C.C.F.; validation, J.A.G. and C.C.F.; formal analysis, J.A.G.; investigation, J.A.G and C.C.F.; resources, J.A.G.; writing-original draft preparation, J.A.G.; writing - review and editing, C.C.F.; visualization, J.A.G. All authors have read and agreed to the published version of the manuscript.

Funding: This research received no external funding.

Data Availability Statement: The data presented in this study are available on request from the corresponding author.

Acknowledgments: We acknowledge the University of Guadalajara for its support and for financing the APC. We also recognize the research team of the institute for their unconditional support during this research. Finally, we want to thank the reviewers; their feedback helped us to improve the quality of our manuscript.

Conflicts of Interest: The authors declare no conflict of interest.

\author{
Abbreviations \\ BGI Blue-Green Infrastructure \\ CRCWSC Cooperative Research Centre for Water Sensitive Cities in Australia \\ MAG Metropolitan Area of Guadalajara \\ PROAGUA Program for drinking water, drainage and wastewater treatment \\ POS Public Open Spaces \\ SIAPA Servicios de Agua Potable y Alcantarillado \\ UWMTF Urban Water Management Transitions Framework \\ WSC Water Sensitive Cities
}




\section{References}

1. Niemczynowicz, J. Urban hydrology and water management-Present and future challenges. Urban Water 1999, 1, 1-14. [CrossRef]

2. Estrada, F.; Botzen, W.J.W.; Tol, R.S.J. A global economic assessment of city policies to reduce climate change impacts. Nat. Clim. Chang. 2017, 7, 403-406. [CrossRef]

3. Bai, X.; Surveyer, A.; Elmqvist, T.; Gatzweiler, F.W.; Güneralp, B.; Parnell, S.; Prieur-Richard, A.H.; Shrivastava, P.; Siri, J.G.; Stafford-Smith, M.; et al. Defining and advancing a systems approach for sustainable cities. Curr. Opin. Environ. Sustain. 2016, 23, 69-78. [CrossRef]

4. Brown, R.; Keath, N.; Wong, T. Transitioning to Water Sensitive Cities: Historical, Current and Future Transition States. In Proceedings of the 11th International Conference on Urban Drainage, Edinburgh, Scotland, UK, 23-26 September 2008.

5. Adger, W.N.; Arnell, N.W.; Tompkins, E.L. Successful adaptation to climate change across scales. Glob. Environ. Chang. 2005, 15, 77-86. [CrossRef]

6. Dolman, N.; Özerol, G.; Bormann, H.; Lijzenga, S. How water sensitive is your city? Benchmarking and navigation in planning for climate adaptation of midsize cities in the North Sea region. In International Water Week; SIWI: Singapore, 2020.

7. De Haan, F.J.; Ferguson, B.C.; Adamowicz, R.C.; Johnstone, P.; Brown, R.R.; Wong, T.H.F. The needs of society: A new understanding of transitions, sustainability and liveability. Technol. Forecast. Soc. Chang. 2014, 85, 121-132. [CrossRef]

8. Dolman, N.; Ogunyoye, F. How water challenges can shape tomorrow's cities. Proc. Inst. Civ. Eng. Civ. Eng. 2019, 172, 13-15. [CrossRef]

9. Hoyer, J.; Dickhaut, W.; Kronawitter, L.; Weber, B. Water Sensitive Urban Design Principles and Inspiration for Sustainable Stormwater Management in the City of the Future; Jovis: Berlin, Germany, 2011.

10. Brears, R.C. Blue and Green Cities: The Role of Blue-Green Infrastructure in Managing Urban Water Resources; Palgrave Macmillan: London, UK, 2018; ISBN 9781137592583.

11. Brown, R.; Rogers, B.; Werbeloff, L. Moving toward Water Sensitive Cities A Guidance Manual for Strategists and Policy Makers; Cooperative Research Centre for Water Sensitive Cities: Clayton, Australia, 2016; ISBN 978-1-921912-35-1.

12. CATCH an Interreg North Sea Region; European Union "Water Sensitive Cities: The answer to challenges of extreme weather events" Available online:. Available online: https:/ / northsearegion.eu/catch/ (accessed on 11 December 2020).

13. De Urbanisten and Deltares. Towards a Water Sensitive Public Space as a Rain Management Strategy MEXICO CITY.; De Urbanisten: Rotterdam, The Netherland, 2016.

14. St. George Freeman, S.; Brown, C.; Cañada, H.; Martinez, V.; Palma Nava, A.; Ray, P.; Rodriguez, D.; Romo, A.; Tracy, J.; Vázquez, E.; et al. Resilience by design in Mexico City: A participatory human-hydrologic systems approach. Water Secur. 2020, 9 , 100053. [CrossRef]

15. Ilgen, S.; Sengers, F.; Wardekker, A. City-To-City Learning for Urban Resilience: The Case of Water Squares in Rotterdam and Mexico City. Water 2019, 11, 983. [CrossRef]

16. Manuel-Navarrete, D.; Morehart, C.; Tellman, B.; Eakin, H.; Siqueiros-García, J.M.; Hernández Aguilar, B. Intentional disruption of path-dependencies in the Anthropocene: Gray versus green water infrastructure regimes in Mexico City, Mexico. Anthropocene 2019, 26, 100209. [CrossRef]

17. Casiano Flores, C.; Crompvoets, J.; Ibarraran Viniegra, M.E.; Farrelly, M. Governance Assessment of the Flood's Infrastructure Policy in San Pedro Cholula, Mexico: Potential for a Leapfrog to Water Sensitive. Sustainability 2019, 11, 7144. [CrossRef]

18. Bigurra-Alzati, C.A.; Ortiz-Gómez, R.; Vázquez-Rodríguez, G.A.; López-León, L.D.; Lizárraga-Mendiola, L. Water Conservation and Green Infrastructure Adaptations to Reduce Water Scarcity for Residential Areas with Semi-Arid Climate: Mineral de la Reforma, Mexico. Water 2020, 13, 45. [CrossRef]

19. Godinez Madrigal, J.; van der Zaag, P.; van Cauwenbergh, N. A half-baked solution: Drivers of water crises in Mexico. Proc. Int. Assoc. Hydrol. Sci. 2018, 376, 57-62. [CrossRef]

20. Validvia, L.; Castillo, M.; González, A. Las Inundaciones En La Zona Metropolitana De Guadalajara. Cart. Económica Reg. 2016, 17, 29-37.

21. Barnett, T. The Town that Refuses to Drown. Earth Isl. J. 2020. Available online: https://www.earthisland.org/journal/index. $\mathrm{php} /$ magazine/entry/the-town-that-refuses-to-drown/ (accessed on 23 December 2020).

22. Wong, T. Water Sensitive Urban Design. Aust. J. Water Resour. 2006, 10, 1-10.

23. United Nations Goal 6: Ensure access to water and sanitation for all. Available online: https:/ /www.un.org/sustainabledevelopment/ water-and-sanitation/ (accessed on 2 December 2020).

24. Bell, J.; Waters, S. Doing Your Research Project, 6th ed.; McGraw Hill: Glasgow, UK, 2014.

25. Denicolo, P.; Becker, L. Developing Research Proposal, 1st ed.; SAGE Publications: London, UK, 2012.

26. Martínez, P.C. El método de estudio de caso: Estrategia metodológica de la investigación científica. In Pensamiento E Gestión; Universidad del Norte: Barranquilla, Colombia, 2006; Volume 20, pp. 165-193.

27. Press Academia. Available online: https://www.pressacademia.org/definition-of-case-study/ (accessed on 1 January 2020).

28. Flyvbjerg, B. Five Misunderstandings about Case-Study Research. Qual. Inq. 2006, 12, 219-245. [CrossRef]

29. Yin, R.K. Case Study Research: Design and Methods, 5th ed.; SAGE Publications: Newbury Park, CA, USA, 1989.

30. Casiano Flores, C. Context Matters: Water Governance Assessment of the Wastewater Treatment Plant Policy in Central Mexico. Ph.D. Thesis, University of Twente, Enscehde, The Netherlands, 2017. [CrossRef] 
31. Grant, G. The Water Sensitive City, 1st ed.; Wiley-Blackwell: London, UK, 2016.

32. Donofrio, J.; Kuhn, Y.; McWalter, K.; Winsor, M. Research Article: Water-Sensitive Urban Design: An Emerging Model in Sustainable Design and Comprehensive Water-Cycle Management. Environ. Pract. 2009, 11, 179-189. [CrossRef]

33. Jalisco-Gobierno del Estado ÁREA METROPOLITANA DE GUADALAJARA. Available online: https://www.jalisco.gob.mx/es/ jalisco/guadalajara (accessed on 16 December 2020).

34. CONAGUA. Pmpms Para Usuarios Urbanos De Agua potable Y Saneamiento; Comisión Nacional del Agua: Mexico city, Mexico, 2015.

35. CEAJ. Ficha Técnica Hidrológica del Municipio de Guadalajara; Gobierno de Jalisco: Guadalajara, Mexico, 2015.

36. Loera, M. Crecimiento Poblacional y Mala Planeación Urbana Ocasionan Desabasto de Agua en la ZMG.; University of Guadalajara: Guadalajara, Mexico, 2018.

37. Agencias Noticias $1400 \mathrm{mdp}$, costo anual de un SIAPA ineficiente. NNC.MX. 2011. Available online: https://nnc.mx/categoria/ portada/1400-mdp-costo-anual-de-un-siapa-ineficiente/58672 (accessed on 7 December 2020).

38. CONAGUA. Programa Hídrico Estatal 2014-2018 del Estado de Jalisco; Gobierno del Estado de Jalisco: Guadalajara, Mexico, 2015.

39. Gran Castro, J.A.; Ramos De Robles, S.L. Climate change and flood risk: Vulnerability assessment in an urban poor community in Mexico. Environ. Urban. 2019, 31, 75-92. [CrossRef]

40. SIAPA. Junta de Gobierno del SIAPA. Available online: https://www.siapa.gob.mx/gobierno/consejo-de-administracion (accessed on 16 December 2020).

41. CONAGUA. Manual de Operación y Procedimientos, Programa de Agua Potable, Drenaje y Tratamiento; Comisión Nacional del Agua: Mexico city, Mexico, 2020.

42. Torres, A. Abastecimiento de agua potable en las ciudades de México: El caso de la zona metropolitana de Guadalajara, Agua y Territorio; Universidad de Jaen: Guadalajara, Mexico, 2013; pp. 77-90.

43. Hernández, A. Agua y Economía: Una Propuesta Hidrológica Para Guadalajara, 1st ed.; ITESO: Tlaquepaque, Mexico, 2001.

44. Gleason Espíndola, J.A.; Cordova, F.; Casiano Flores, C. The importance of urban rainwater harvesting in circular economy: The case of Guadalajara city. Manag. Res. Rev. 2018, 41, 533-553. [CrossRef]

45. Rijke, J.; Farrelly, M.; Brown, R.; Zevenbergen, C. Configuring transformative governance to enhance resilient urban water systems. Environ. Sci. Policy 2013, 25, 62-72. [CrossRef]

46. Özerol, G.; Dolman, N.; Bormann, H.; Bressers, H.; Lulofs, K.; Böge, M. Urban water management and climate change adaptation: A self-assessment study by seven midsize cities in the North Sea Region. Sustain. Cities Soc. 2020, 102066. [CrossRef]

47. Dobbie, M.F.; Brown, R.R.; Farrelly, M.A. Risk governance in the water sensitive city: Practitioner perspectives on ownership, management and trust. Environ. Sci. Policy 2016, 55, 218-227. [CrossRef]

48. Informador. Deterioro del ciclo de agua, problema en Guadalajara: Especialista, Informador MX. 2016. Available online: https:// www.informador.mx/Jalisco/Deterioro-del-ciclo-de-agua-problema-en-Guadalajara-especialista-20160317-0019.html (accessed on 2 December 2020).

49. CEAS. Jalisco Comisión Estatal del Agua. Available online: https://www.ceajalisco.gob.mx (accessed on 4 January 2020).

50. SIAPA. Informe de Actividades SIAPA Tercer Trimestre. 2019. Available online: https://www.siapa.gob.mx/sites/default/files/ doctrans/9_informe_de_actividades_siapa_3er._trimestre_19.pdf (accessed on 4 January 2020).

51. Wong, T.; Ashley, R. International Working Group on Water Sensitive Urban Design submission to the IWA/IAHR Joint Committee on Urban Drainage; IWA/IAHR: Burlington, OT, Canada, March 2006.

52. Newman, P.; Mouritz, M. Principles and planning opportunities for community scale systems of water and waste management. Desalination 1996, 106, 339-354. [CrossRef]

53. CONAGUA. Determinación de la Disponibilidad de Agua Subterránea en el Acuífero de Atemajac, Estado de Jalisco; CONAGUA: Ciudad de México, México, 2015.

54. CONAGUA. Actualización de la Disponibilidad Media Anual de Agua Subterránea en el Acuifero de Toluquilla, Estado de Jalisco; CONAGUA: Ciudad de México, México, 2015.

55. Imeplan Plan De Ordenamiento Territorial Metropolitano Del Amg. Available online: https://www.imeplan.mx/sites/default/ files/IMEPLAN/POTmet_IIIFB-BajaRes.pdf (accessed on 5 January 2020).

56. Gleason, J. Groundwater Management in the Metropolitan Zone of Guadalajara: The case Aquifer Recharge Zone called “El Bajío de Arenal". In Proceedings of the IWA Specialist Groundwater Conference, Belgrade, Serbia, 9-11 June 2016.

57. Flash flooding traps passengers in Guadalajara transit cars. Mex. News Dly. 2018. Available online: https://mexiconewsdaily. com/news/flash-flooding-traps-passengers-in-guadalajara/ (accessed on 2 December 2020).

58. Forbes, M. Zapotillo dam opponents find support from key Federal Official but not Mexico's President. Guadalajara Report, 1 August 2019. Available online: https://theguadalajarareporter.net/index.php/columns/columns/michael-forbes/53848zapotillo-dam-opponents-find-support-from-key-federal-official-but-not-mexico-s-president(accessed on 10 November 2020).

59. Ramírez, V. Construction of Urban Development at River Confluence. Available online: https://www.eloccidental.com.mx/ local/piden-vecinos-de-cantaluna-pagos-e-infraestrura-para-evitar-inundaciones-como-la-del-2018-3310359.html (accessed on 6 January 2020).

60. Hernández Guízar, R. Se está hundiendo el mercado Mexicaltzingo. Página 24 Jalisco 2018. Available online: https://pagina2 4jalisco.com.mx/2018/04/06/local/se-esta-hundiendo-el-mercado-mexicaltzingo/ (accessed on 11 November 2020). 
61. Milenio Digital. Colonos de Tlajomulco viven sin agua. Telediario. 2019. Available online: https://gdl.telediario.mx/local/ colonos-de-tlajomulco-viven-sin-agua (accessed on 11 November 2020).

62. Gleason, J. Historia del deterioro del ciclo del agua en el Área Metropolitana de Guadalajara. In Aportaciones técnicas en torno al estudio del arte, la arquitectura y la ciudad.; Núñez, V., Pérez, M., Eds.; University of Guadalajara: Guadalajara, México, 2016; pp. 97-113.

63. Siapa Programa De Manejo Integral De Agua pluvial (Promiap) Y Plan Integral De Manejo De Inundaciones (PIMI). Available online: https:/ / www.siapa.gob.mx/sites/default/files/doctrans/1.-_antecedentes-promiap-pimi.pdf (accessed on 5 January 2020).

64. SINA. Sistema Nacional de Información del Agua. Gobierno de México. Available online: http:/ / sina.conagua.gob.mx/sina/ (accessed on 2 December 2020).

65. CONAGUA. Banco Nacional de Datos de Aguas Superficiales; CONAGUA: Ciudad de México, México, 2020.

66. Sharma, S. Performance Indicators of Water Losses in Distribution System; UNESCI-IHE: Delft, The Netherland, 2008.

67. McCulligh, C. Defiance from Down River; Deflection and Dispute in the Urban-Industrial Metabolism of Pollution in Guadalajara. Sustainability 2019, 11, 6294. [CrossRef]

68. Imeplan: Agenda Metropolitana. Available online: https://imeplan.mx/index.php/en/gobernanza (accessed on 5 January 2020).

69. Casiano Flores, C.; Özerol, G.; Bressers, H.; Kuks, S.; Edelenbos, J.; Gleason, A. The state as a stimulator of wastewater treatment policy: A comparative assessment of three subnational cases in central Mexico. J. Environ. Policy Plan. 2019. [CrossRef]

70. Casiano Flores, C.; Bressers, H.; Gutierrez, C.; de Boer, C. Towards circular economy-A wastewater treatment perspective, the Presa Guadalupe case. Manag. Res. Rev. 2018, 41, 554-571. [CrossRef]

71. Espíndola, J.A.G.; Sánchez, Y.C.; Casiano Flores, C. Mexican rainwater harvesting movement in recent years. In International Rainwater Catchment Systems Experiences; Gleason Espíndola, J.A., Casiano Flores, C., Pacheco-Vega, R., Pacheco, M., Eds.; IWA Publishing: London, UK, 2020; pp. 73-82. [CrossRef]

72. CRC for Water Sensitive Cities. The Climatic Benefits of Green Infrastructure; CRC for Water Sensitive Cities: Clayton, Victoria, Australia, 2017.

73. González, Mariana. Cada habitante del AMG debería tener al menos 9 metros cuadrados de áreas verdes públicas. Universidad de Guadalajara Vicerrectoría Ejecutiva. 2019. Available online: http:/ /www.cga.udg.mx/?q=noticia/cada-habitante-del-amgdeberia-tener-al-menos-9-metros-cuadrados-de-areas-verdes-publicas (accessed on 2 January 2021).

74. World Economic Forum Giant Sponges Cities. Available online: https:/ /www.youtube.com/watch?v=U37gst79pGc (accessed on 5 September 2020).

75. SAIH Sistema Automático de Información Hidrológica de la Cuenca Hidrográfica del Ebro. Available online: http://www. saihebro.com/saihebro/index.php (accessed on 7 January 2020).

76. Melbourne Water. Water Urban Design Guidelines, 1st ed.; Melbourne Water: Melbourne, Australia, 2013.

77. Gleason, J. Gestión y Planeación del Sistema Hidrosanitario del Área Metropolitana de Guadalajara: Un Reto Hacia la Sustentabilidad, 1st ed.; University of Guadalajara: Guadalajara, México, 2016.

78. Brodnik, C.; Holden, J.; Marino, R.; Wright, A.; Copa, V.; Rogers, B.; Arifin, H.S.; Brown, R.; Djaja, K.; Farrelly, M.; et al. Jumping to the top: Catalysts for leapfrogging to a water sensitive city. IOP Conf. Ser. Earth Environ. Sci. 2018, 179, 012034. [CrossRef] 